\title{
DEEP LOOSENING AS EFFECTIVE ADAPTIVE AGROMELIORATIVE PRACTICE ON DRAINED MINERAL SOIL OF EUROPEAN POLESIE IN VARIABLE CLIMATIC CONDITIONS
}

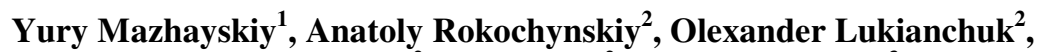 \\ Vasyl Turcheniuk ${ }^{2}$, Pavlo Volk ${ }^{2}$, Olga Chernikova ${ }^{3}$
}

${ }^{1}$ All-Russian Research Institute of Hydrotechnics and Melioration named after A.N. Kostyakova, Russia; ${ }^{2}$ National University of Water and Environmental Engineering, Russia; ${ }^{3}$ Academy of Law Management of the Federal Penal Service of Russia, Russia director@mntc.pro, a.m.rokochinskiy@nuwm.edu.ua, o.p.lukyanchuk@nuwm.edu.ua, v.o.turchenuk@nuwm.edu.ua,p.p.volk@nuwm.edu.ua, chernikova_olga@inbox.ru

\begin{abstract}
In the paper the designs of traditional deep tillers are analyzed and their inconsistency with the requirements for improving the technology of water regulation of ameliorated lands in changing climatic conditions is determined. They do not guarantee the necessary quality of loosening the soil and its structure, compact the soil into the walls of the cut slots, require significant energy costs for implementation, have insufficient completeness of loosening and the duration of its aftereffect. Therefore, it is advisable to switch from the traditional and most widespread technologies of slot and strip loosening to continuous loosening in profile and area, as well as differentiated loosening of deep soil horizons. It is proved that improved deep loosening can be the most effective means of ensuring the necessary filtration and simultaneous accumulation of excess soil moisture to ensure maximum productivity of ameliorated land throughout the entire growing season. Possible approaches to improving the technology and design to obtain more efficient means of deep loosening and the design of an advanced multi-tiered deep tiller are proposed. Thanks to the new principle of deep loosening, for the first time it became possible to control the process of loosening the soil and obtain the desired degree of loosening in each horizon of the developed vertical profile of the soil. In the design of the advanced deep-tiller, the zone of elastoplastic deformations is minimized and is replaced by less energy-intensive shear, chip, and bending deformations due to tiered loosening of the soil by a separate working element at subcritical depths.Its implementation in the conditions of Polesye of Ukraine contributed to the improvement of water-physical properties, water permeability and accumulating ability of the most common drained sod-podzolic soil, which provided an increase in the yield of cultivated crops by $20-40 \%$, as well as an increase in the duration of its aftereffect up to 3-4 years with payback no more than 1 year.
\end{abstract}

Keywords: loosening, agromeliorative practice, soil, Polesie, climatic conditions.

\section{Introduction}

The water management complex is a fairly capital-intensive sector of agricultural production. To maintain the high productivity of waterlogged soil, it is recommended to carry out a number of agromeliorative practices simultaneously with the drainage device, aimed at increasing the accumulating capacity of the active soil layer, improving the surface and subsoil runoff, and enriching the soil with nutrients. Several types of agromeliorative practices are known as special methods of tillage for regulating its moisture by draining excess water from the surface and from the arable layer of soil. One of the most promising agromeliorative techniques in modern conditions is deep cultivation. Deep loosening of ameliorated lands is carried out by special tools to a depth of $0.6-0.8 \mathrm{~m}$ or more to ensure water drainage through loosened soil to closed collectors (drains). They are used on heavy mineral soil, as well as on light loam and sandy loam soil with the presence of dense, poorly permeable to water layers in the subsoil horizons (at a depth of 0.3-0.4 $\mathrm{m}$ and deeper). Loosening of drained soil to a depth of 0.6-0.8 $\mathrm{m}$ against a background of closed drainage improves their waterphysical properties and increases the yield of cultivated crops. The influence of the depth of cultivation on the work of drainage is manifested in an increase in drainage runoff and a decrease in surface runoff. The depth of cultivation has the greatest influence in the first year after it is carried out, in the future its influence decreases.

In today's variable climatic conditions, when theamount and intensity of precipitation, temperature conditions change, the implementation of existing water management technologies on ameliorated lands can further increase the inefficiency of their use. This is manifested in the fact that the unevenness of precipitation and the traditional haphazard drainage of excess water into the open network by drainage systems create significant fluctuations in the groundwater level and the moisture content of the root layer of drained lands during the growing season that leads to inefficient use of 
natural water reserves in the soil. In this case, the lower soil layers become almost waterproof under conditions of long-term operation [1-3].

Despite the fact that the average rainfall over the growing season is $250-400 \mathrm{~mm}$, due to a change in established climatic regimes, crops suffer either from waterlogging with an increase in the intensity and amount of rainfall over a short period of time, or from overdrying of the soil with excessive dry season evaporation. As a result, this leads to crop losses of up to 30-40\%. Amelioration and further agricultural land use change the direction and pace of development of soil processes, as well as the water-physical properties of soil. In general, their productivity increases, but at the same time, they do not completely eliminate the negative soil properties in relation to cultivated crops $[2 ; 4 ; 5]$.

Modern changes in natural conditions, caused primarily by climate changes, lead to a change in the requirements for the rational use of water and land resources in the drainage amelioration zone [12]. As the result, the question of changing the principles for the formation of approaches to water regulation on drained lands and the development of a number of measures to adapt water management complexes to these changes becomes extremely urgent. Instead of the main principle of traditional drainage, which consists in maximally accelerating the transfer of surface runoff to groundwater, and then draining it through the drainage beyond the boundaries of the site, it is more expedient to carry out its maximum accumulation and regulation in the soil and the boundaries of the drained site, but only to discharge the residues through the drainage.

In this regard, the issue of rational use of water and land resources of ameliorated lands defines the following tasks:

- the need to differentiate the degree of drainage of the soil to improve the regulation of surface and subsoil runoff, which is related to the direction and intensity of soil processes,

- simultaneously with the use of drainage, carrying out the agromeliorative practices aimed at increasing the accumulating ability of the active layer of the soil and enriching it with nutrients and the drainage system as a whole.

The purpose of work is to improve the technologies and designs of technical means for effective implementation of deep loosening, taking into account certain tasks.

Deep loosening does not require significant investment and is a fairly effective agromeliorative practice. In variable climatic conditions, deep loosening can be themost effective adaptive measure and an alternative to expensive reconstruction of existing amelioration systems, including systems of European Polesie.

Polesie is a unique physical and geographical region, which is located on the territory of the Polesie lowland almost in the center of Europe. Polesie (in Belorussian - Палесce, in RussianПолесье, in Polish - Polesie) is a peculiar landscape region of the Eastern European physical and geographical region, it has an area of about 300 thousand $\mathrm{km}^{2}$.

There are Lublin (Poland), Belarusian (Belarus), Ukrainian (Ukraine), Bryansko-Zhizdrinskoe, Orlovsko-Kaluzhskoe Polesie (Russia). In Ukraine - Volynskoe, Zhytomyrskoe, Kievskoe, Chernigovskoe, Novgorod-Severskoe".

Polesie is a unique natural complex. Amelioration has become a significant factor in the socioeconomic transformations of this region and plays an important role in the development of economic sectors. Ameliorated waterlogged lands are important in the humid zone of Ukraine, and they are the only guarantors of stable farming and creation of a reliable forage base to meet the needs of animal husbandry, regardless of weather and climatic conditions in many regions. Therefore, the Polesie zone of Ukraine is the main area for drainage amelioration.

The use of deep loosening as an effective adaptive measure in variable climatic conditions determines the need for its improvement.

Traditional deep loosening involves crevice loosening of the soil by rack-mounted working bodies. In this case, vertical channels are formed in the soil profile to transfer the entire surface runoff to the subsoil and then drain it through the drainage. In the current conditions of alternating periods of drought and excessive humidity, this technology can cause significant negative environmental consequences due to the increased leaching regime of the land. In case of excess moisture, the 
drainage system, which is originally designed to be more gentle, will be heavily overloaded. In case of a dry period the soil will be unproductive.

It is advisable to change the principle of traditional deep loosening - the transition from technologies of local crevice loosening of the vertical soil profile and strip loosening over the area to a continuous area and differentiated loosening of the soil profile depth.

The practice and the accumulated experience of agricultural production, according to which the vertical soil profile of farmland should have an anti-erosion top layer $(0-0.05 \mathrm{~m})$, a root-inhabited layer $(0.05-0.4 \mathrm{~m})$ and a lower filtration layer $(0.4-0.8 \mathrm{~m})$, additionally speaks in favour of this. At the same time, the optimal soil structure (the percentage by weight of the groups of lumps of "valuable" and other sizes) of each of these layers is different and should be appropriate for each of them [5].

\section{Materials and methods}

For deep loosening of soil, depending on the conditions and type of the soil, different types of tillers are used: with active and passive working bodies [6-8].

Active deep tillers belong to pulsed-power machines. During loosening the soil, they use various types of vibration and shock loads on the soil. Theworking body of an active deep-tiller develops the soil due to the flow of energy coming from an autonomous source that allows using the additional vibrational energy to reduce the energy intensity of soil loosening. But this is justified only for surface tillers and at low speeds of the tiller moving. With an increase in the speed of movement of the traction vehicle and an increase in depth, the effect of the vibrating working equipment decreases significantly, and the energy consumption increases significantly compared to passive working equipment [7].

The working equipment of the passive deep tiller develops the soil and carries out its longitudinal movement due to the pulling force of the base tractor only.

Active and passive-active deep-tillers are much more complicated than relatively passive ones in design and operation. They are effective only on hard (rocky) and dense soil, and on relatively soft non-frozen soil they have practically no advantages over the passive ones.

Therefore, the most widespread tillers are passive deep-tillers. They are reliable, simple in design and in operation, but require more powerful tractors.

In many countries, for deep loosening, quite simple in design and reliable in operation tools are used, including a frame on supporting wheels or a hinged one with several ripping or shear working elements mounted on it.

Agricultural and agromeliorative deep tillers of a traditional and modern design are rack-mount or perimeter working bodies that loosen the soil to a maximum depth of mainly $0.30-0.35 \mathrm{~m}$ - agrarian, and up to $0.45-0.65 \mathrm{~m}$ - agromeliorative.

The rack-mounted deep-tillers (single and multi-rack) during the passage extend the surface of the soil $10-15 \mathrm{~cm}$ upward in zones of $15-20 \mathrm{~cm}$ on both sides of the tracks of the risers, and in the spaces between them - by $3-4 \mathrm{~cm}$. The degree of loosening of soil in the zone near the racks $-8-12 \%$, in the zone between the racks - 40-60\% $[5 ; 6]$.

Perimeter working equipments are characterized by the same drawbacks as rack-mounted, namely: pressing and grouting the soil into the side walls of the cut slots, great resistance to movement, and the inability to predict and obtain the required quality of loosening in the horizons of the vertical profile of loosening the soil.

Therefore, based on the foregoing, the designs of traditional deep-tillers do not guarantee the necessary quality of loosening the soil, their structure, and protection of the soil from technological impact. They condense the soil of the walls of the cut slots, require significant energy consumption when loosening, andhave insufficient completeness of loosening and the duration of the aftereffect.

Thus, the effectiveness of improving deep cultivation is constrained by the imperfection of existing technologies and tools that do not provide the necessary quality and efficiency of loosening, and therefore require further improvement in accordance with the following requirements [5; 11]: to provide a long after-effect; to improve the water-physical properties and structure of the soil, to increase its fertility; to provide high accumulating and sorption abilities of the soil, to increase the 
efficiency of its water regulation; to ensure resource conservation, high economic and energy efficiency; to meet modern principles of adaptive nature management.

Comparison of the technological efficiency of various technologies and deep loosening equipment was carried out according to the experimental results of 3 years of testing in the "Uyezdtsy" experimental section and in the "Pechalivka" drained massif in the Rivne region of Ukraine $[5 ; 11]$. The soil of the studied object is represented by sod-podzolic gley sandy loam sand, formed under conditions of a close occurrence of the groundwater level. The filtration coefficient of the arable soil layer $(0-20 \mathrm{~cm})$ is $0.13-0.4 \mathrm{~m} \cdot \mathrm{day}^{-1}$, and at the depth of $20 \mathrm{~cm}$ or more $-0.13-0.003 \mathrm{~m} \cdot \mathrm{day}^{-1}$. Soil conditions are typical for the physical and geographical area of the Western (Volyn) Polesie of Ukraine.

Study of various technologies and means of deep loosening on water-physical properties of soils and land improvement status and operation of the existing drainage system in general, conducted to the following options: slit loosening to a depth of $0.6 \mathrm{~m}$ with two-tier deep-ripper type RU -45; strip loosening to a depth of $0.6 \mathrm{~m}$ three-tier deep-ripper of a new type with one riser in each tier; solid loosening to a depth of $0.6 \mathrm{~m}$ two-tier deep-ripper of a new type with three risers in each tier (Fig. 1); control version without loosening. The experimental sites were placed in the form of a "Latin square".

The operational equipment of the new type of deep-thrower consists of a frame with variable risers (1-3 pcs in each tier), on which the loosening elements are fixed in the form of the conjugation of the horizontal knife (cutter) with the concave symmetric surface of the variable curvature.

\section{Results and discussion}

In order to eliminate the shortcomings of traditional deep loosening tools and take into account the necessary technological changes, new working equipments with a multi-level arrangement of risers and an improved working element were developed and tested (Fig. 1) [9].

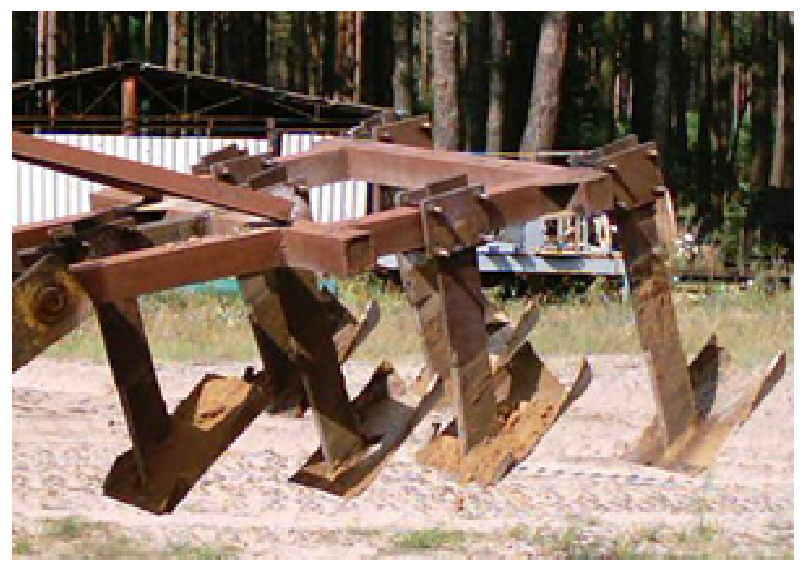

Fig. 1. Working equipment for deep continuous cultivation of the soil with improved racks

In general, the working equipment of such a tiller consists of a frame with load-bearing racks, on which work elements are fixed at different levels (tiers) in the form of a horizontal knife mating with a concave symmetrical grooved loosening surface of variable curvature. Through the shape and parameters of this surface, the required deformation, degree of stress, and, consequently, grinding of the developed soil layer are set. The general arrangement of the working body of the deep-tiller is determined by spatial spacing of the working elements in three mutually perpendicular directions.

The use of such working equipment ensures the creation of favorable conditions for the restoration of the water-physical state of the soil in each layer simultaneously over the entire area and profile of the soil (Fig. 2).

Soil loosening by multi-tier working bodies is characterized by a decrease in the density in the arable layer to $1.1-1.15 \mathrm{t} \cdot \mathrm{m}^{-3}$, in the subsoil - to $1.2-1.3 \mathrm{t} \cdot \mathrm{m}^{-3}$, which corresponds to a loosening coefficient within 1, 23-1.32; the prevalence of soil aggregates up to $25-50 \mathrm{~mm}$ across ( $<25 \mathrm{~mm}-$ $65 \%$; $<50 \mathrm{~mm}-93 \%$ ) in the structural composition of the loosened layer; an increase in porosity by 
$25-35 \%$, an increase in the permeability of the loosened layer by more than 4 times to $1.36 \mathrm{~m} \cdot \mathrm{day}^{-1}$, and an increase by 3.5 times of water loss.
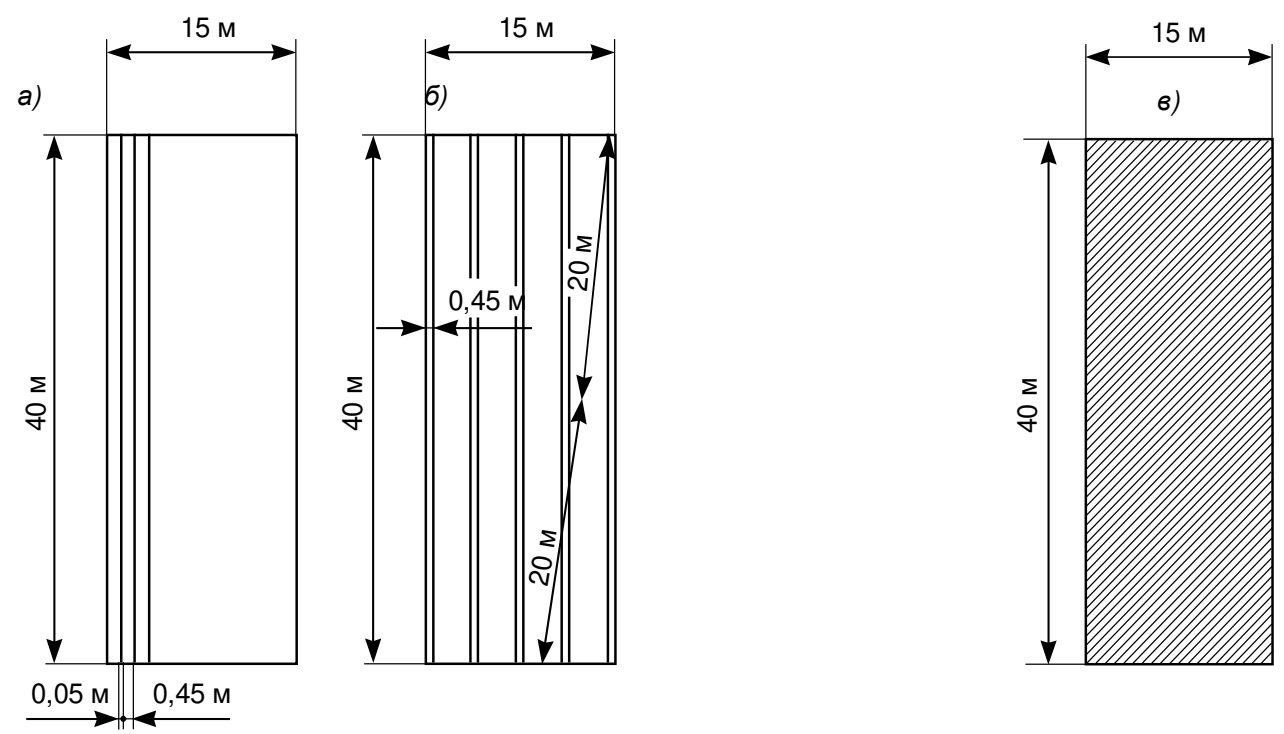

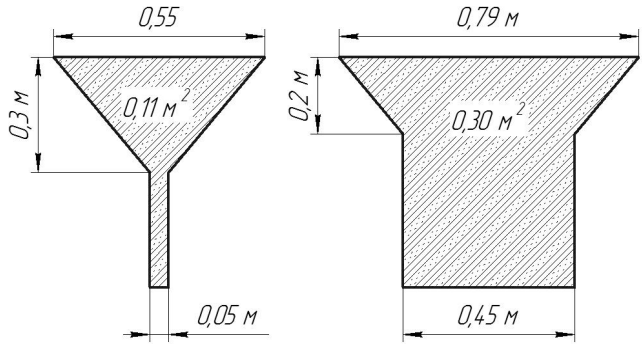

a)

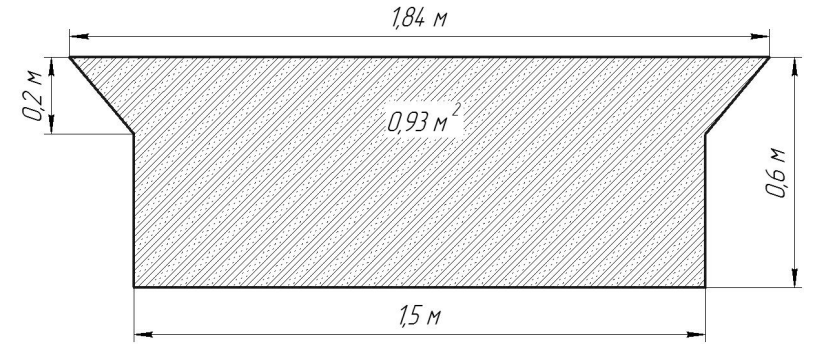

b)

c)

Fig. 2. Comparative diagram of the variants for completeness of loosening the soil by area (in the top) and profile (in the bottom) in a single site: a - slotted loosening by a single-rack deep-tiller; $\mathrm{b}$ - strip loosening by a three-rack deep-tiller; $\mathrm{c}$ - continuous differentiated loosening by a multi-tier deep-tiller [11]

The option of performing the working elements separate and swept from two symmetrical grooved parts with the gradual principle of grinding the soil layer was adopted for subsequent use during the process of improving the design (Fig. 3).
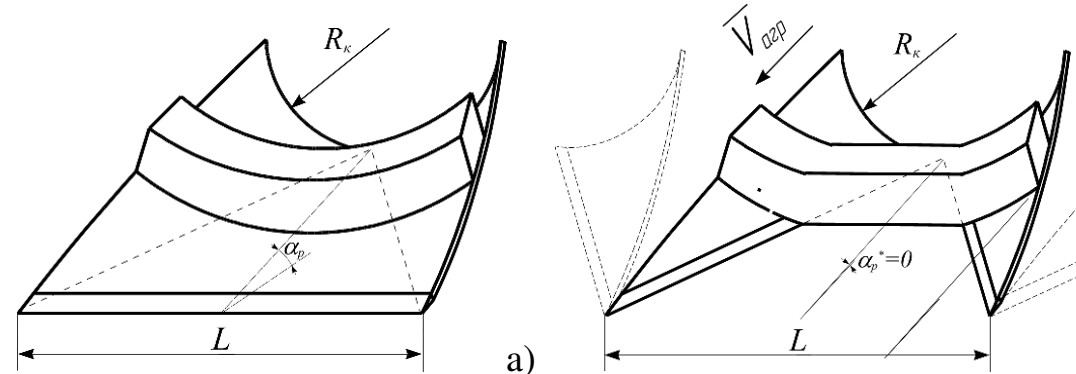

b)

Fig. 3. Variants of the working elements of the deep-tiller: $a$ - grooved; $b$ - sharp jib

If we consider the principles of grinding the soil layer by working elements, then in general they are similar, but there are some differences. In one variant (Fig. 3, a), with the cultivator moving, soil shavings cut by each horizontal knife move along the loosening element and gradually bends from the edges to the middle as a result of the grooved shape of the last one and is structured by bending in two coordinate planes, reaching calculated indicators at the end of the surface. Loosening of the soil occurs evenly and simultaneously across the entire width of the cut soil layer with the rise along the surface of the loosening element to the cutting angle. 
In another case (Fig. 3, b), due to the different curvature and sweep of the symmetric radial surfaces of the loosening elements, the differentiation of the quality of loosening of the soil in depth occurs with less traction resistance of the working body due to the gradual grinding of the soil layer without its precutting by a horizontal sharer and additional friction from subsequent movement through the loosening element.

Considering the above, the variant with gradual grinding should have an advantage in the towing force of the tractor, since it lacks unproductive transportation and lifting of the soil, although there may be some slight loss in the cutting force of the soil in next tier to the current one.

In qualitative terms, the sequence diagram of grinding is almost the same and should give an identical final indicator of soil loosening.

On the basis of the sharp jib variant of the implementation of the loosening elements, working equipments were developed for carrying out continuous differentiated loosening with reduced energy consumption for effective control of the filtration and moisture accumulation for soil of various types (Fig. 4) that is taken into account in the form of a transverse profile of loosened soil: rectangular - for light soil, trapezoidal - for medium soil and triangular - for heavy soil.
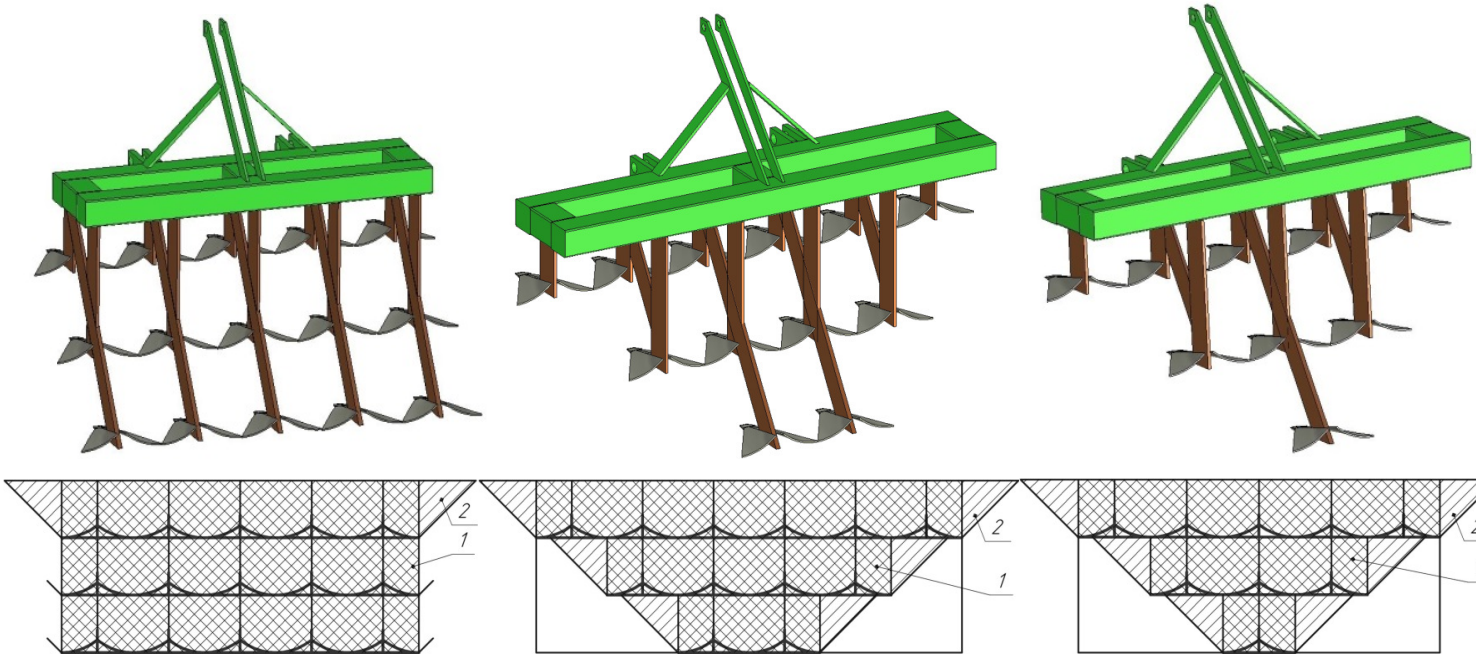

a)

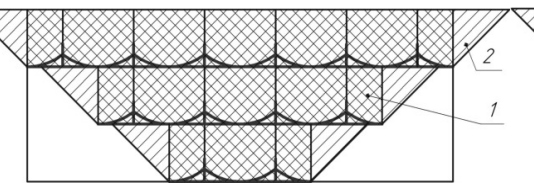

b)

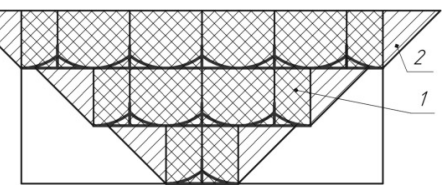

c)

Fig. 4. Deep tillers for soil of various types (design option and completeness of loosening of the transverse profile): $\mathrm{a}$ - for light soil (sandy loam and light loam); $\mathrm{b}$ - for medium soil (medium loam) $\mathrm{c}$ - for heavy soil (heavy loam, clay); 1 - complete structural loosening;

\section{2 - partial loosening by cleavage}

The working equipments of such deep-tillers consist of a frame with oblique load-bearing racks, on which there are fixed loosening elements in tiers in the form of two concave symmetric arrow radial semi surfaces of equal shift curvature with the smallest radius of curvature at the exit from them, the size of which is proportional to the size of the planned structural element of the soil of a separate tier.

Partially, the effectiveness of the use of deep-tillers can be estimated by the coefficient of completeness of loosening (general and structural) - the ratio of the area of loosened soil in the frontal plane to the area of the conditional rectangle of loosening in the frontal plane (determined by the total width and depth of loosening of the working body). The coefficient of general loosening characterizes the increase in the volume of loosened soil relative to the initial volume, and structural - the volume of formation of the necessary structural aggregates in the loosened soil volume relative to the original volume.

In such working equipment the coefficient of overall completeness of loosening of the transverse profile is in the range of 0.40-1.05, and the coefficient of completeness of structural loosening is in the range of 0.4-1.0. The highest values of coefficients in deep-tillers for continuous differentiated loosening of sandy loam and light loamy soil (1.05 and 1.00, respectively), intermediate values in 
deep-tillers for differentiated loosening of medium loamy soil ( 0.8 and 0.67 , respectively), the smallest values in deep-tillers for differentiated loosening of heavy loamy soil (0.76 and 0.60 , respectively).

At the same time, the authors determined that due to the design features, such working bodies can carry out both strip and continuous cultivation, if it is necessary, and such tillers can have up to $40 \%$ less specific resistance to movement during cultivation than in traditional existing deep-tillers [5; 9; 11].

Various means and methods of deep loosening provide different levels of environmental reliability of drained mineral soil. Previously, the authors determined the use of continuous loosening by the multi-tier deep-tiller, in contrast to slot and strip one, increased the ecological reliability coefficient of ameliorated soil from 0.31 - not environmentally reliable value, to 0.52 - ecological reliable value, and thereby ensured the maintenance of a favorable ecological and ameliorative state of soil $[10 ; 11 ; 13 ; 14]$.

The summary results of the application of the new technology show the effectiveness of continuous differentiated deep loosening and are presented through graphical dependences of the experimentally obtained physical, energy, and filtration characteristics on the Rc coefficient of completeness of soil loosening in the researched massif with a thickness of $0.6 \mathrm{~m}$, Fig. 5.

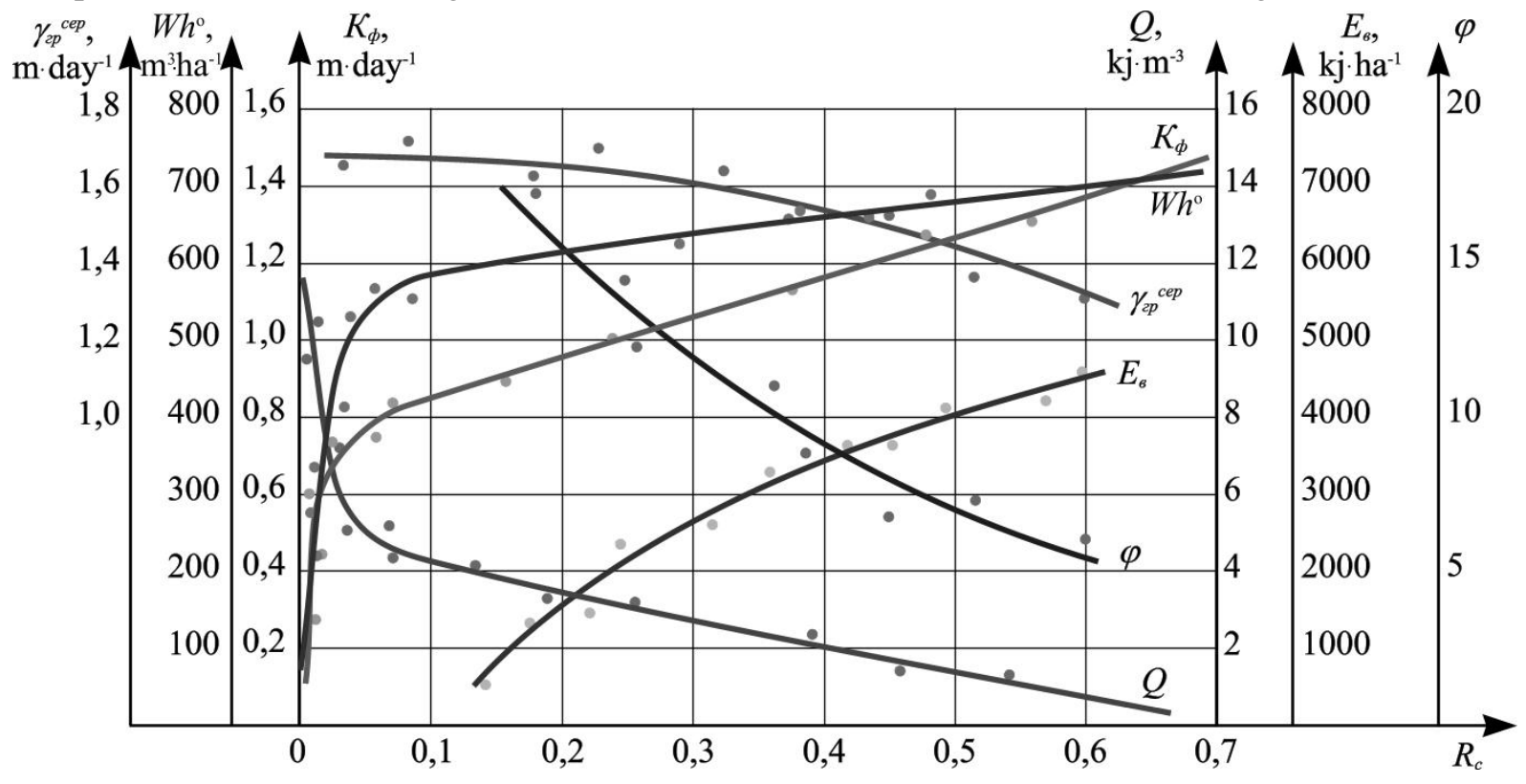

Fig. 5. Dependence of physical, energy and filtration characteristics on the $\boldsymbol{R}_{c}$ coefficient of completeness of soil loosening in the researched massif with a thickness of $0.6 \mathrm{~m}: \gamma_{z p}{ }^{c e p}$-average soil density at the experimental site in the layer of $0.6 \mathrm{~m} ; E_{b}$ - integral indicator of energy consumption; $Q$ - indicator of the specific energy consumption for loosening $1 \mathrm{~m}^{3} ; \varphi$-coefficient of energy equivalent (potential) of the obtained agricultural products; $K_{\phi}$-filtration coefficient; $W h^{\circ}$ - maximum reserve of productive soil moisture

\section{Conclusions}

1. In today's variable climatic conditions, it is advisable to switch from the traditional and most common technologies of slot and strip loosening to continuous in profile and area, as well as differentiated in deep horizons loosening of the soil.

2. Improved deep loosening is an effective adaptive tool for the accumulation of free soil moisture in case of the transition from technologies of slot and strip loosening to continuous in area and differentiated in depth soil loosening.

3. Due to the new principle of deep loosening, for the first time it became possible to control the process of loosening of the soil, namely, to obtain the desired degree of loosening in each horizon of the vertical profile of the soil, that is, to differentiate the loosening structure by depth.

4. The proposed solution is one of the most effective adaptive means of increasing land productivity in agricultural production and at the same time an alternative measure of expensive reconstruction 
of existing ameliorative systems in the absence of sufficient funds for this in variable climatic conditions. Its implementation in the conditions of Polesie of Ukraine contributed to the improvement of water-physical properties, water permeability and accumulating ability of drained the most common sod-podzolic soil that provided an increase in the yield of cultivated crops by $20-40 \%$, as well as an increase in the duration of its aftereffect to 3-4 years in case of payback no more than 1 year.

\section{References}

[1] Iglesias A., Garrote L., Adaptation strategies for agricultural water management under climate change in Europe. Agricultural Water Management, vol. 155, 2015, pp. 113-124.

[2] Ward P.R., Flower K.C., Cordingley N and others, Soil water balance with cover crops and conservation agriculture in a Mediterranean climate. Field Crops Research. vol. 132, 2012, pp. 3339.

[3] Hamzaa M.A., Anderson W.K., Soil compaction in cropping systems: A review of the nature, causes and possible solutions. Soil and Tillage Research. vol. 82, is. 2, 2005, pp. 121-145.

[4] Медведєв В.В., Лактіонова Т.М., Почепцова Л.Г. Вплив структури грунту на фільтраційну здатність (Influence of soil structure on filtration ability ) Visn. agrar science. vol. 3. pp. 5-8. (In Ukrainian).

[5] Науково-методичні рекомендації до застосування глибокого розпушення на осушуваних мінеральних грунтах Західного Полісся України (Scientific and methodical recommendations for applying deep loosening on drained mineral soils of the Western Polissia of Ukraine)/ В.С. Гавриш, В.Ф. Ткачук, П.І. Мендусь, Г.І. Сапсай та ін., 2013, 46 p. (In Ukrainian).

[6] Mikchail Laziuta, Bajan Kabulova, Chalit Gasanov. Research of soil tillage by advanced design slit ripper. Agricultural Engineering. Research papers, 2016 , vol. 45, No. 2. Policy, vol. 59, 2016, pp. 152-164.

[7] Кравець С.В., Скоблюк М.П., Стіньо О.В., Зоря Р.В. Критичноглибинні двоярусні грунторозпушувачі (наукові основи створення) (Critical-pitched two-level soil rippers (scientific basis of creation)): Monograph / According to the general edition of S.V. Kravets Rivne: NUWEE, 2018, 235 p. (In Ukrainian).

[8] Пивовар В. Глибокорозпушувачі. Інформаційно-аналітична газета «Агробізнес Сьогодні». Механізація АПК (Deep rippers. Information and analytical newspaper Agrobusiness today. Mechanization of AIC), 2011, [online] [31.03.2019]. Available at: http://agrobusiness.com.ua/agro/mekhanizatsiia-apk/ item/847-hlybokorozpushuvachi.html (in Ukrainian).

[9] Lukyanchuk O.P., Ryzhyi O.P., Ihnatiuk R.M. Design of a tiered operating unit for deep differentiated tillage. Scientific Bulletin of the National Mining University, 2017, Is. 4, pp.43-48, P.6.

[10]Lukyanchuk O.P., Turcheniuk V.O., Prykhodko N.V., Volk P.P., Rokochinskiy A.M. Necessity and possible approaches to applying deep loosening when cultivating rice/.// INMATEH Agricultural Engineering. Vol. 57,No.1/ 2019. Pages: 199-207. (In Ukrainian).

[11]Природообустройство Полесья: монография: в 4 кн. / под общ. науч. ред. Ю. А. Мажайского, А. Н. Рокочинского, А. А. Волчека, О. П. Мешика, Е. Езнаха. (Environmental management of Polesie): monograph in 4 books. Ryazan. Book 2, 2017, vol. 1.902 (In Russian).

[12] Kovalenko, P., Rokochynskiy, A., Jeznach, J., Koptyuk, R., Volk, P., Prykhodko, N., Tykhenko, R. Evaluation of climate change in Ukrainian part of Polissia region and ways of adaptation to it. Journal of Water and Land Development, 2019, 41 (IV-VI). pp. 77-82.

[13]Касьянов A. Е. Экологически безопасное глубокое мелиоративное рыхление (Environmentally friendly deep reclamation loosening) Environmental management, Russian State Agrarian University - Moscow Agricultural Academy K.A. Timiryazeva (Moscow), 2015. vol. 4 - pp.19-21. (In Russian).

[14]Касьянов А. Е. Природоохранные технологии осушительных мелиораций (Environmental technologies for drainage reclamation): a monograph. - Moscow: Federal State Budgetary Educational Institution of Higher Professional Education "Moscow State University Of Environmental Development”, 2012. - 196 p. (In Russian). 